4. In perfusions with human blood the average rate of synthesis of albumin, measured by direct isolation, was $12.9 \mathrm{mg}$./ $\mathrm{hr}$. for a liver from a $300 \mathrm{~g}$. rat. By an indirect method of calculation, based on the specific radioactivity of isolated albumin and the total radioactivity incorporated into plasma protein, it was $11 \mathrm{mg}$./hr. In perfusions with rat or human blood the average rate of synthesis of albumin, calculated from the amounts of $\left[{ }^{14} \mathrm{C}\right]$ lysine incorporated into plasma protein and the specific activities of free lysine in the plasma, was $5 \mathrm{mg}$./hr. The possibility is discussed that the difference is due to the fact that the specific activity of lysine at the site of synthesis was less than that in the plasma.

5. A non-protein ${ }^{14} \mathrm{C}$-labelled basic substance other than lysine has been found to accumulate during these perfusions.

We acknowledge with pleasure the skilled technical assistance of $\mathrm{Mr}$ Louis Assemakis, and numerous discussions with Dr S. Cohen and Dr A. S. McFarlane.

\section{REFERENCES}

Askonas, B. A. \& Humphrey, J. H. (1958). Biochem. J. 70, 212.

Bradley, J. E. S., Holloway, R. C. \& McFarlane, A.S. (1954). Biochem. J. 57, 192.
Campbell, R. M., Cuthbertson, D. P., Matthews, C. M. \& McFarlane, A. S. (1956). Int. J. appl. Radiat. Isotopes, 1, 66.

Cohen, S. \& Gordon, A. H. (1958). Biochem. J. 70, 544.

Delaville, M., Delaville, G. \& Delaville, J. (1954). Ann. pharm. franc. 12, 109.

Flynn, F. V. \& de Mayo,.P. (1951). Lancet, ii, 235.

Freeman, T. \& Matthews, C. M. E. (1958). Strahlentherapie, 38, 283.

Gornall, A. C., Bardawill, C. J. \& David, M. M. (1949). J. biol. Chem. 177, 751.

Humphrey, J. H. \& Sulitzeanu, B. D. (1958). Biochem. J. $68,146$.

Jacobs, S. (1956). Analyst, 81, 502.

Jensen, D. \& Tarver, H. (1956). J. gen. Physiol. 39, 567.

Loftfield, R. B. \& Eigner, E. A. (1958). J. biol. Chem. 231, 925.

Lowry, O. H., Rosebrough, N. J., Farr, A. L. \& Randall, R. J. (1951). J. biol. Chem. 193, 265.

McFarlane, A. S. (1958). Nature, Lond., 182, 53.

Miller, L. L., Bly, C. G., Watson, M. L. \& Bale, W. F. (1951). J. exp. Med. 94, 431.

Moore, S., Spackman, D. H. \& Stein, W. H. (1958). Analyt. Chem. 30, 1185.

Peterson, E. A. \& Sober, H. A. (1956). J. Amer. chem. Soc. 78, 751.

Porath, J. (1954). Acta chem. scand. 8, 1813.

Schwert, G. W. (1957). J. Amer. chem. Soc. 79, 139.

Spector, W. S. (1956). Handbook of Biological Data. London: W. B. Saunders Co.

Steinbock, H. L. \& Tarver, H. (1954). J.biol. Chem. 209, 127.

Biochem. J. (1960) 75, 247

\title{
The Extraction of Pigments from Euglena gracilis
}

\author{
By S. S. EPSTEIN AND JACQUELINE B. WEISS \\ The Hospital for Sick Children, Great Ormond Street, London, W.C. 1
}

(Received 7 September 1959)

Euglena gracilis is a flagellated green alga commonly employed in the microbiological assay of vitamin $\mathbf{B}_{12}$. As a preliminary to assay, biological fluids are ideally diluted to contain about $10 \mu \mu \mathrm{g}$. of vitamin $B_{12} / \mathrm{ml}$. and a series of standards covering a range of $0 \cdot 25-50 \mu \mu \mathrm{g} . / \mathrm{ml}$. is in general use. Growth is usually assessed in a colorimeter 6-7 days after commencement of the assay (Ross, 1952; Hutner, Bach \& Ross, 1956). The response thus measured is dependent both on turbidity and colour of the Euglena suspension.

In the course of experiments on potential vitamin $\mathrm{B}_{12}$ antimetabolites (Timmis \& Epstein, 1959; Epstein \& Petrow, 1960), a series of compounds was screened for inhibitory activity against $E$. gracilis grown at low concentrations of vitamin $B_{12}$. Compounds found active on screening weresubsequently tested again to determine whether their antagonism was competitive in nature and therefore susceptible to reversal by massive vitamin concentrations. In this type of experiment, however, both growth and pigment production, particularly in the standards, became so prolific that the ensuing response could no longer be assessed by the methods referred to above (i.e. measuring both turbidity and colour). The object of this paper is to present a simple and sensitive pigment-extraction technique by which this difficulty may be obviated.

\section{EXPERIMENTAL}

Assay of vitamin $B_{12}$. The test organism was Euglena gracilis var. $z$. The method, including basal growth medium, was based on that described by Hutner et al. (1956). 
Standard vitamin $B_{12}$ solutions covering a range of $0-1000 \mu \mu \mathrm{g} . / \mathrm{ml}$. were tested in triplicate. The solutions (4 ml., consisting of $2 \mathrm{ml}$. of double-strength basal medium and $2 \mathrm{ml}$. of double-strength vitamin standard in water) were incubated in capped Pyrex tubes for 6 days at $28^{\circ}$, after which $4 \mathrm{ml}$. of acetone was added to each tube. The tubes were then sealed with the thumb and mixed by vigorous shaking for approx. $5 \mathrm{sec}$. After $10 \mathrm{~min} .3 \mathrm{ml}$. of ethyl acetate was added and the tubes were again shaken for a further $5 \mathrm{sec}$. After $10 \mathrm{~min}$. the tubes were quickly shaken again and the green supernatant solvent layer was transferred to a cuvette with a $5 \mathrm{~mm}$. light path and read in an EEL (Evans Electroselenium Ltd.) colorimeter at $660-680 \mathrm{~m} \mu$ (filter no. 608).

Some estimates of growth at low concentrations of vitamin $\mathrm{B}_{12}$ were made by the method of Hutner et al. (1956) (i.e. measuring both turbidity and pigment), with the same colorimeter and filter; this method is referred to throughout the paper as the standard method. The two methods were also compared at high concentrations of vitamin $B_{12}$ by diluting the cultures. Serial dilutions of cultures grown with 100 and $1000 \mu \mu \mathrm{g}$. of vitamin/ml. were read and extinctions plotted against concentration.

All results reported in this paper were obtained in triplicate and only mean readings are given.

Examination of pigments. The absorption curve of pigment extracted as described above was measured in a Hilger Uvispek spectrophotometer.

Chromatographic analyses of pigment extracts were carried out on sucrose-impregnated Whatman no. 1 filter paper (Sporer, Freed \& Sancier, 1954), in the dark at room temperature. The chromatograms were examined both in visible and ultraviolet light.

Measurement of cell numbers and cell size. Algae were counted in a Fuchs-Rosenthal chamber after being killed by the addition of one drop of diluted (1:400) $40 \%$ formaldehyde soln. to each tube.

By a modified Biggs \& MacMillan (1948) technique, cellsize distributions of 100 algae from cultures grown respectively with $0,10,100$ and $1000 \mu \mu \mathrm{g}$. of vitamin $B_{12} / \mathrm{ml}$. were measured. Cell images were projected orthogonally on to 22 in. $\times 30$ in. sheets of 1 in. graph paper by a Leitz micro-projector. The projected cells were outlined in pencil and cut out and weighed. The mean weight of six separate 1 in. $\times 1$ in. squares from different parts of each sheet of paper was used for calibration in conjunction with a projected micron scale. One sheet of paper only was used for each concentration of vitamin $B_{12}$. In this way it was possible to express the recorded weights in terms of square microns (surface area).

Application of the extraction technique to antimetabolite studies. This was studied with from 0 to $500 \mu \mathrm{g}$. of 6mercaptopurine $/ \mathrm{ml}$., at $100 \mu \mathrm{g}$. intervals, each concentra. tion of 6-mercaptopurine being tested in the presence of 0 , 10,100 and $1000 \mu \mu \mathrm{g}$. of vitamin $B_{12} / \mathrm{ml}$. respectively. The growth response at 6 days was assessed by the extraction method.

\section{RESULTS}

Pigments extracted by solvent. Pigment is completely extracted from algal cultures by the method described above. even in the tubes containing $1000 \mu \mu \mathrm{g}$. of vitamin $B_{12} / \mathrm{ml}$.; there was no colour in the cellular residues and aqueous phase. Separation into two layers is rapid and complete. The disrupted cells sediment to the bottom of the assay tubes, and the solvent layer at the interface is debris-free. The green supernatant layer (approx. $3.5 \mathrm{ml}$.) is translucent. The bands of the absorption spectrum of the extract resembled those observed in solutions of chlorophylls $a$ and $b$ in other solvents (Zscheile \& Comar, 1941; Sprecher von Bernegg, Heierle \& Almasy, 1935).

The extinctions of the coloured extract at serial dilutions were determined in the colorimeter and also at two peak absorption bands (670 and $420 \mathrm{~m} \mu$ ) in the spectrophotometer. A linear relationship was obtained at $670 \mathrm{~m} \mu$ and in the colorimeter up to extinctions of 2.0 and 0.7 respectively, and the colour is stable at room temperature for $12 \mathrm{hr}$. At $420 \mathrm{~m} \mu$, however, where linearity is equally good, absorption is too great to allow estimation at the required concentrations (Fig. 1).

The chromatograms of freshly extracted pigments and of pigments stored at room temperature in the light for $12 \mathrm{hr}$. are identical.

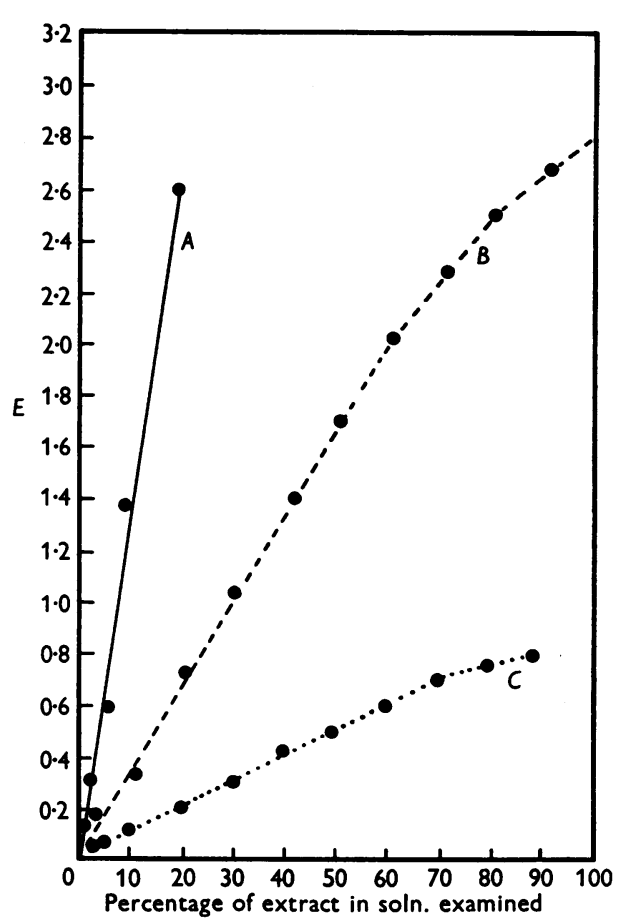

Fig. 1. Relationship between concentrations of extracted pigment from Euglena gracilis and extinction. The extract was prepared from a culture of Euglena containing $1000 \mu \mu \mathrm{g}$. of vitamin $B_{12} / \mathrm{ml}$. The extract was diluted with acetone. $A, B$, Readings at 420 and $670 \mathrm{~m} \mu$ in the spectrophotometer; $C$, colorimeter reading. 
Table 1. Comparison of results of standard and extraction methods for measuring growth response of Euglena gracilis

Readings were measured in an EEL colorimeter, filter no. 608. Each result is the mean of 18 estimations.

\begin{tabular}{|c|c|c|c|c|}
\hline \multirow[b]{2}{*}{$\begin{array}{l}\text { Concn. of } \\
\text { vitamin } \mathrm{B}_{12} \\
(\mu \mu \mathrm{g} \cdot / \mathrm{ml} .)\end{array}$} & \multicolumn{2}{|c|}{ Standard method } & \multicolumn{2}{|c|}{ Extraction method } \\
\hline & $\begin{array}{l}\text { Colorimeter } \\
\text { readings }\end{array}$ & $\begin{array}{c}\text { Coefficient of } \\
\text { variation } \\
(\%)\end{array}$ & $\begin{array}{l}\text { Colorimeter } \\
\text { readings }\end{array}$ & $\begin{array}{l}\text { Coefficient of } \\
\text { variation } \\
(\%)\end{array}$ \\
\hline $\begin{array}{r}5 \\
10\end{array}$ & $\begin{array}{l}24 \cdot 5 \\
47 \cdot 0\end{array}$ & $7 \cdot 0$ & $12 \cdot 5$ & $6 \cdot 5$ \\
\hline
\end{tabular}

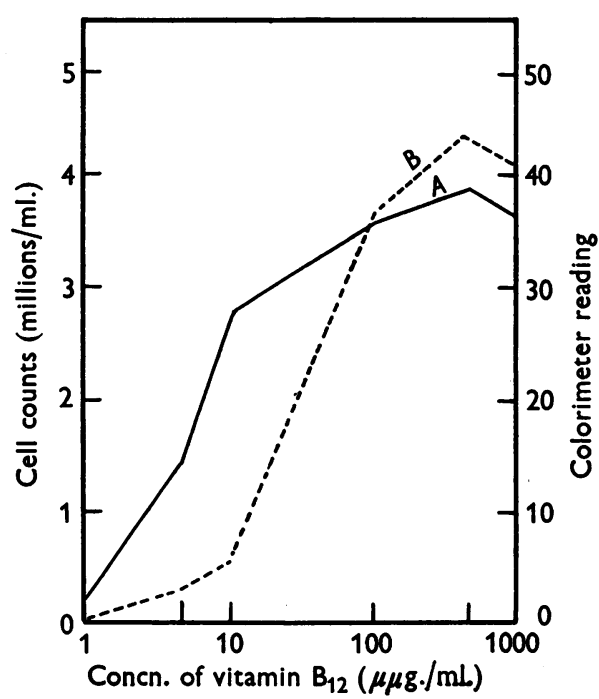

Fig. 2. Comparison between colorimeter readings of extracted pigments from cultures of Euglena gracilis $(A)$ and cell counts from these same cultures $(B)$.

Relation between extracted pigment and vitamin $B_{12}$ concentration. Colorimeter readings of extracted pigments from algal cultures were compared with cell counts from the same cultures. Pigment production does not appear to increase as much as cell population between 10 and $100 \mu \mu \mathrm{g}$. of vitamin $\mathrm{B}_{12} / \mathrm{ml}$. (Fig. 2).

Standard and extraction methods were performed in the same assay tubes at low concentrations of vitamin $B_{12}$; both methods gave comparable results (Table 1). Comparisons at high concentrations of vitamin $B_{12}$ could not be effected; in the standard method of assay not only was excessive dilution required to obtain readings in the colorimeter, but also such dilutions did not show a linear relationship with concentration.

Variation of cell size with vitamin $B_{12}$ concentration. The mean cell size increases significantly between 0 and $10 \mu \mu \mathrm{g}$. of vitamin $B_{12} / \mathrm{ml}$. and is markedly decreased at 100 and $1000 \mu \mu \mathrm{g}$. of vitamin $B_{12} / \mathrm{ml}$. (Table 2). The standard error of distribution of cell size is large in the absence of the vitamin and small with $100 \mu \mu \mathrm{g}$. of vitamin $B_{12} / \mathrm{ml}$. (Fig. 3).
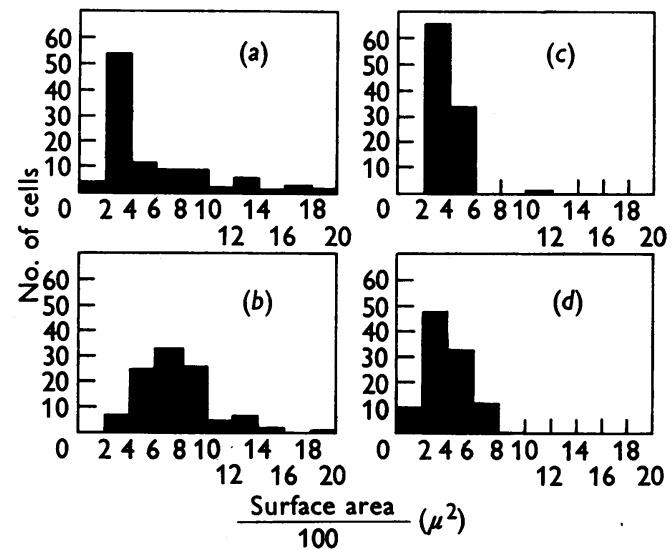

Fig. 3. Distribution of cell size $\left(\mu^{2}\right)$ of Euglena gracilis at (a) 0 , (b) 10, (c) 100 and (d) $1000 \mu \mu \mathrm{g}$. of vitamin $\mathrm{B}_{12} / \mathrm{ml}$. Each step represents the number of cells at a given surface area and each plot represents the average of results obtained from ten different cultures.

Table 2. Mean surface area of cells of Euglena gracilis at various concentrations of vitamin $B_{12}$

The growth period in all cases was 6 days.

$\begin{array}{ccc}\begin{array}{c}\text { Concn. of } \\ \text { vitamin } B_{12}\end{array} & \begin{array}{c}\text { Mean surface } \\ \text { area }\end{array} & \begin{array}{c}\text { s.D. of } \\ (\mu \mu \mathrm{g} . / \mathrm{ml} .)\end{array} \\ \left(\mu^{2}\right) & \text { distribution } \\ 0 & 455 & 356 \\ 10 & 687 & 253 \\ 100 & 299 & 5 \cdot 6 \\ 1000 & 326 & 129\end{array}$

Table 3. Results of an antagonist experiment with 6-mercaptopurine and the pigment-extraction technique

Results are expressed as colorimeter readings (EEL). Each value is the mean for three extracts.

\begin{tabular}{|c|c|c|c|c|}
\hline \multirow{2}{*}{$\begin{array}{l}\text { Concn. of } \\
\text { 6-mercaptopurine } \\
(\mu \mathrm{g} . / \mathrm{ml} .)\end{array}$} & \multicolumn{4}{|c|}{ Vitamin $B_{12}(\mu \mu \mathrm{g} \cdot / \mathrm{ml})}$. \\
\hline & 0 & $\begin{array}{c}10 \\
\text { Colorimete }\end{array}$ & $\begin{array}{l}100 \\
\text { readings }\end{array}$ & 1000 \\
\hline 0 & 2 & 33 & 68 & 69 \\
\hline 100 & $\mathbf{l}$ & 28 & 72 & 65 \\
\hline 200 & 1 & 18 & 68 & 63 \\
\hline 300 & 0 & 18 & 67 & 60 \\
\hline 400 & 0 & 10 & 61 & 59 \\
\hline 500 & 0 & 8 & 60 & 57 \\
\hline
\end{tabular}


Experiment with 6-mercaptopurine. The results of the antagonist experiment with 6-mercaptopurine are presented in Table 3 . It can be deduced graphically from these results that the approximate concentrations of 6-mercaptopurine required to produce $50 \%$ inhibition of growth at 10, 100 and $1000 \mu \mu \mathrm{g}$. of vitamin $\mathrm{B}_{12} / \mathrm{ml}$. are $200,>500$ and $>500 \mu \mathrm{g} \cdot / \mathrm{ml}$. respectively.

\section{DISCUSSION}

The method of pigment extraction described in this paper is simple and accurate and can be conveniently applied over a very wide range of concentrations of vitamin $B_{12}$. The entire procedure is performed in the original assay tube and the extracted pigments are stable. The standard method of assessing the growth response of $\boldsymbol{E}$. gracilis and the extraction method are both equally suitable at the usual range of vitamin $B_{12}$ concentrations assayed in serum, but at high concentrations the standard method is unsatisfactory.

Ostrowki, Skarzynski \& Zak (1954) described a methanol method for the extraction of pigment from algal cultures, but this entails centrifuging of individual tubes, and with profuse growth the use of massive volumes of methanol. Similarly, Wolken \& Palade (1953) used $80 \%$ acetone or methanol to extract portions of algal cultures. Quantitative assessment of growth at high concentrations of vitamin $B_{12}$ is difficult by the standard method, because of the ensuing high turbidity of $E$. gracilis cultures. Indeed the problem of high turbidities was encountered even at relatively low vitamin concentrations by Hutner et al. (1956).

Comparison between pigment concentration and cell counts reveals that these are not directly related. However, it does appear that pigment concentration is related to cell volume; at $10 \mu \mu \mathrm{g}$. of vitamin $B_{12} / \mathrm{ml}$. there is an abundance of pigment per cell with comparatively few cells of large mean diameter but with considerable individual variation in size. At $100 \mu \mu \mathrm{g} . / \mathrm{ml}$., however, there is relatively little pigment per cell and numerous but small cells of approximately equal sizes. In the standard method of assessing growth response of $E$. gracilis, pigment is measured in conjunction with the turbidity due to the cells present. These cells vary considerably in size with different concentrations of vitamin $B_{12}$ and this fact must contribute an inaccuracy; turbidimetric methods in general depend on the assumption of homogeneity of particle size.

The application of the $E$. gracilis test system to the study of vitamin $B_{12}$ antimetabolites has so far received little attention. This is possibly a reflexion of the technical difficulties in the measurement of growth at high vitamin concentrations. Hendlin \&
Soars (1951) tested the effect of 1:2-diamino-4:5dimethylbenzene, 5:6-dimethylbenzimidazole and related compounds on the growth of Lactobacillus lactis Dorner and E. gracilis. They stated that growth response of $E$. gracilis had been determined turbidimetrically, but no results were given. Funk \& Nathan (1958) relied on turbidimetric measurements to observe the inhibition of $E$. gracilis by benzimidazole at high concentrations of vitamin $B_{12}$, and maintained that under their conditions the growth response was linear at 7 days $(H . B$. Funk \& H. A. Nathan, personal communication).

The antagonist experiment with 6-mercaptopurine illustrates the applicability of the pigmentextraction method to antimetabolite studies. The results indicate that the antagonism is competitive in nature, as it can be partially reversed by high concentrations of vitamin $B_{12}$.

\section{SUMMARY}

1. Pigments were extracted from cultures of Euglena gracilis by means of an acetone-ethyl acetate-solvent system. This technique permits the measurement of growth response of this alga over a wider range of vitamin $B_{12}$ concentrations than has hitherto been possible.

2. A direct relationship has been demonstrated between pigment concentration and cell size.

3. The application of the solvent-system technique to vitamin $B_{12}$-antimetabolite studies is illustrated by an experiment with 6-mercaptopurine.

This work was supported in part by a British Empire Cancer Campaign grant (to S.S.E.). We are grateful to Mr P. Payne for statistical comments, Mr G. M. Timmis and Dr M. Lubran for criticizing the manuscript and Mr P. Bush for enthusiastic and skilled technical assistance. We would also like to thank Mr G. Lyth for the preparation of charts and Mrs R. Martin for typing the manuscript.

\section{REFERENCES}

Biggs, R. \& MacMillan, R. L. (1948). J. clin. Path. 1, 269. Epstein, S. S. \& Petrow, V. (1960). Nature, Lond., (in the Press).

Funk, H. B. \& Nathan, H. A. (1958). Proc. Soc. exp. Biol., N.Y., 99, 394

Hendlin, D. \& Soars, M. H. (1951). J. Bact. 62, 633.

Hutner, S. H., Bach, M. K. \& Ross, G. I. M. (1956). J. Protozool. 3, 101.

Ostrowski, W., Skarzynski, B. \& Zak, Z. (1954). Acta biochim. polon. 1, 13.

Ross, G. I. M. (1952). J. clin. Path. 5, 250.

Sporer, A. H., Freed, S. \& Sancier, K. M. (1954). Science, 119, 68.

Sprecher von Bernegg, A., Heierle, E. \& Almasy, F. (1935). Biochem. Z. 283, 45.

Timmis, G. M. \& Epstein, S. S. (1959). Nature, Lond., 184, 1383.

Wolken, J. J. \& Palade, G. F. (1953). Ann. N.Y. Acad. Sci. 56, 873.

Zscheile, F. P. \& Comar, C. L. (1941). Bot. Gaz. 102, 463. 